\title{
Orange Flavedo Incorporated Functional Lassi
}

\author{
K. V. Ananthakumar and Rita Narayanan* \\ Department of Livestock Products Technology (Dairy Science), Madras Veterinary College, \\ Tamil Nadu Veterinary and Animal Sciences University, Chennai \\ *Corresponding author
}

\section{A B S T R A C T}

\begin{tabular}{|l|}
\hline Ke y w o r d s \\
Orange flavedo, \\
$\begin{array}{l}\text { Fermented dairy } \\
\text { beverage, Lassi } \\
\text { beverage }\end{array}$ \\
\hline Article Info \\
$\begin{array}{l}\text { Accepted: } \\
\text { 18 December } 2020 \\
\text { Available Online: } \\
\text { 10 January } 2021\end{array}$ \\
\hline
\end{tabular}

Keywords

Orange flavedo, Fermented dairy beverage, Lassi Article Info

Accepted: Available Online: 10 January 202

\section{Introduction}

Lassi is one such traditional fermented beverage having its origin in India and is popular in South Asia in different varieties. It is a nutritious and easily digestible beverage, Anon (1997). Mild acidic flavour and sweetish taste of lassi makes it a refreshing drink. It can also be made salted and spiced by adding salt and spices like ginger, coriander, and mint in the form of a paste in the place of sugar. Generally, those who are intolerant to milk may be more tolerant to curds or yoghurt. Increasing curds, lassi or yoghurt may be the best option. Hence this fermented beverage can be consumed by people who are lactose intolerant, Manus (1979). The product is relished sweet in northern part of the India, whereas the sour variety is preferred in the south, Aneja et al., (2002).

A number of novel fermented dairy products have been developed and marketed under the concept of innovative confectionary goods. Orange peel which is a waste by-product in juice industry can be utilized as it has a higher level of vitamin $\mathrm{C}$ than the pulp and also contribute cellulosic material, essential oils, fatty acids, pigments besides flavour. Adewole et al., (2014) found that the crude fibre is around $12.47 \%$. Hanan et al., (2012) 
considered the citrus peels as a functional food supplement in certain food products because they are ranked as a good source of dietary fibres, volatile oils, phenolic compounds, minerals and vitamins. Savita et al., (2010) revealed that the ascorbic acid content in fresh peel was $82.45 \mathrm{mg} / 100 \mathrm{~g}$ while the orange peel candy had ascorbic acid content of $32.7 \mathrm{mg} / 100 \mathrm{~g}$ which was a good source of ascorbic acid.

Any starch can be pearled by heating and stirring small aggregates of moist starch, producing partly gelatinized dry kernels which swell but remain intact on boiling. Pearl sago closely resembles pearl tapioca. Both are typically small (about $2 \mathrm{~mm}$ diameter) dry, opaque balls. Both may be white (if very pure) or coloured naturally grey, brown or black, or artificially pink, yellow, green, etc. When soaked and cooked, both become much larger, translucent, soft and spongy. Both are widely used in Indian, Bangladeshi and Sri Lankan cuisine in a variety of dishes and around the world, usually in puddings is used in a variety of dishes such as desserts boiled with sweetened milk on occasion of religious fasts. In India,

"Tapioca Sago -Sabudana" is considered an acceptable form of nutrition during periods of fasts for religious purposes or for infants or ill persons. Sago from metroxylon palms is nearly pure carbohydrate and has very little protein, vitamins, or minerals. 100 grams of dry sago typically comprises 0.5 grams of dietary fibre, $10 \mathrm{mg}$ of calcium, $1.2 \mathrm{mg}$ of iron.

In this study, sago and the peels of orange were added to lassi to enhance flavour and as functional addition. Thus the objective of this research was to bring a new innovative functional beverage by utilizing orange peel by simple processing technique.

\section{Materials and Methods}

Two cups (100gms) of fresh chilled homemade curd was whisked in a blender till it was smooth. The curd should be smooth before adding other ingredients to it. Ten table spoon $(5 \mathrm{gm})$ of sugar was added. Two cups $(100 \mathrm{ml})$ of chilled water was added. The consistency of this lassi was neither thin nor thick. It was blended till the sugar dissolved with foam formation. Orange peel was dried in fluidized bed dryer at a temperature of below $60^{\circ} \mathrm{C}$ for $50-55 \mathrm{~min}$ by evaporating the moisture level in the peel and made into powder by using blender and made fine powder. The orange peel powder was then added at varying levels to the lassi viz., at 1.5, 2.5, 3.5 and 5 per cent. Boiled tapioca pearls (Sago) were incorporated at the rate of $40 \%$ to the lassi.

\section{Ascorbic acid quantification}

Ascorbic acid was estimated by using titration method (2, 6- dichloro phenol indophenol dye) as per Vasantha Kumar et al., (2013).All the samples were thoroughly cleaned using deionised water to remove adhering contaminants. For the analysis of vitamin $\mathrm{C}$ in the samples, determination was done on the same day of purchase to counteract the instability of vitamin $\mathrm{C}$. Vitamin $\mathrm{C}$ was determined by using the procedure as outlined by Food Analysis Laboratory Manual (FSSAI, 2012).

Determination by Indophenol Method by Association of Official Agricultural Chemists (AOAC,1997).10 $\mathrm{g}$ of each of the samples with the exception of fruits was accurately weighed and ground using mortar and pestle with an additional of $20 \mathrm{~mL}$ of metaphosphoric acid acetic acid. The mixture was further ground and strained through muslin and the extract was made up to 100 $\mathrm{mL}$ with the metaphosphoric-acetic acid 
mixture. $5 \mathrm{~mL}$ of the metaphosphoric acidacetic acid solution was pipetted into three of the $50 \mathrm{~mL}$ Erlenmeyer flask followed by 2 $\mathrm{mL}$ of the samples extract. The samples were titrated separately with the indophenol dye solution until a light rose pink persisted for 5 seconds.

The amount of dye used in the titration were determined and used in the calculation of vitamin $\mathrm{C}$ content. Determination of vitamin $\mathrm{C}$ in fruits was done by extracting the juice using juice extractor and $2 \mathrm{~mL}$ of the muslinfiltered juice was used in titration for the determination of vitamin $\mathrm{C}$.

Conc. of Vitamin C in Lassi $(\mathrm{mg} / \mathrm{ml})=$ DCIP (ml) used to titrate Lassi /DCIP (ml) used to titrate Standard x 1mg/ml.

DCIP - Dicholoro indophenols dye

Antioxidant activity (DPPH free radical scavenging assay): [Ref - Blois MS 1958]

Stock solution of DCIP was prepared to the concentration of $10 \mathrm{mg} / \mathrm{ml}$. Different concentration of the sample (200, 400 and $600 \mu \mathrm{L}$ ) of sample were added to an equal volume of methanolic solution of DPPH $(0.1 \mathrm{mM})$. The reaction mixture was incubated for $30 \mathrm{~min}$ at room temperature and $\%$ of absorbance was recorded at $517 \mathrm{~nm}$. The experiment was repeated for three times. Ascorbic acid was used as standard control. The annihilation activity of free radicals was calculated in \% inhibition according to the following formula.

$\%$ of Inhibition $=(\mathrm{A}$ of control $-\mathrm{A}$ of Test $) / \mathrm{A}$ of ascorbic acid (control)* 100.

There was an increase in antioxidant activity of the $2.5 \%$ incorporated Orange flavedo lassi beverage as the concentration of the sample $(200,400$ and $600 \mu \mathrm{L})$ increases i.e at $600 \mu \mathrm{L}$ it has the maximum activity. The antioxidant activity was found to be $63.32 \%(600 \mu \mathrm{L}$ concentration) indicating the functionality of this fermented beverage.

\section{Sensory evaluation}

Sensory analysis was conducted by a team of 11 trained panellists. 9 point hedonic scale was used for assessing the sensory attributes from like extremely to dislike extremely. The main objective of the study was to analyze the sensory scores of the various samples of different concentrations of the lassi beverage and ranked different samples according to their sensory qualities.

On estimation of acidity and $\mathrm{pH}$ of the Lassi beverage the $2.5 \%$ Orange Flavedo incorporated Lassi was found to have lesser Acidity and $\mathrm{pH}$ than that of the control.

The Vitamin C level of the $2.5 \%$ incorporated Orange Flavedo Lassi and fresh orange peel was estimated by Indophenol dye method which was nearly the same level as compared. On sensory analysis using 9 point hedonic scale, the attributes like colour and appearance, Body \& Texture, Flavour, Sweetness, Sourness and overall acceptability have been analyzed and found $2.5 \%$ orange flavedo incorporated functional lassi to be best among all other attributes.

\section{Results and Discussion}

Tiwari (1998) concluded that the lassi was white to creamy-white, viscous liquid with rich aroma and sweet taste. The general sensory attributes colour, flavour, homogeneity and taste were also ranked according to their importance in the overall acceptability of the lassi drinks.

The sensory evaluation of the beverage samples was found that the $2.5 \%$ was the 
most acceptable. The quality attributes were ranked as Taste > Flavour > Homogeneity > Colour, showing the highest importance of taste and least importance of the colour as a quality attribute in case of lassi beverages. Along with the increase in food production, there is the requirement of advanced technologies for the effective preservation of food. (Khurana, 2006). Sago from
Metroxylon palms is nearly pure carbohydrate and has very little protein, vitamins, or minerals. 100 grams of dry sago typically comprises 94 grams of carbohydrate, 0.2 grams of protein, 0.5 grams of dietary fiber, $10 \mathrm{mg}$ of calcium, $1.2 \mathrm{mg}$ of iron and negligible amounts of fat, carotene, thiamine and ascorbic acid and yields approximately 355 calories.

Table.1 Ascorbic acid (Vitamin C) level of the sample and fresh orange peel

\begin{tabular}{|l|l|l|}
\hline & Acidity \% LA & pH \\
\hline Control & $\mathbf{0 . 4 2} \pm \mathbf{0 . 0 0 8}$ & $\mathbf{4 . 0 3} \pm \mathbf{0 . 0 4 2}$ \\
\hline $\begin{array}{l}\mathbf{2 . 5 \%} \text { Orange Flavedo } \\
\text { incorporated Lassi }\end{array}$ & $\mathbf{0 . 3 6} \pm \mathbf{0 . 0 0 3 3}$ & $\mathbf{4 . 2 6} \pm \mathbf{0 . 0 3 3}$ \\
\hline
\end{tabular}

Table.2 Sensory attributes of orange flavedo incorporated functional lassi (Mean \pm SE) ${ }^{@}$

\begin{tabular}{|l|l|}
\hline Contents & Vitamin C level \\
\hline Fresh orange peel & $138 \mathrm{mg} / 100 \mathrm{~g}$ \\
\hline $\begin{array}{l}2.5 \% \text { Orange flavedo incorporated } \\
\text { functional lassi }\end{array}$ & $136 \mathrm{mg} / 100 \mathrm{~g}$ \\
\hline
\end{tabular}

Table.3 Antioxidant activity of $2.5 \%$ incorporated Orange flavedo lassi beverage

\begin{tabular}{|c|c|c|c|c|c|c|}
\hline Trails & Color \& Appearance & $\begin{array}{l}\text { Body \& } \\
\text { Texture }\end{array}$ & Flavor & Sweetness & Sourness & $\begin{array}{c}\text { Overall } \\
\text { acceptability }\end{array}$ \\
\hline Control & $(5.33+0.21)^{c}$ & $\begin{array}{c}(6.66+ \\
0.42)^{\mathrm{ab}_{*}}\end{array}$ & $\begin{array}{c}(4.16+ \\
0.3)^{d}\end{array}$ & $\begin{array}{c}(7.5+ \\
0.22)^{\mathrm{ab}_{*}}\end{array}$ & $\begin{array}{l}(6.66+ \\
0.21)^{b_{*}}\end{array}$ & $\begin{array}{l}(5.1+ \\
0.7)^{c}\end{array}$ \\
\hline $1.5 \%$ & $(5.66+0.21)^{b c_{*}}$ & $\begin{array}{l}(6.16+ \\
0.3)^{\mathrm{bc}_{*}}\end{array}$ & $\begin{array}{c}(4.83+ \\
0.3)^{\mathrm{d}}\end{array}$ & $\begin{array}{l}(7.83+ \\
0.30)^{\mathrm{a}}\end{array}$ & $\begin{array}{c}(7.33+ \\
0.21)^{\mathrm{ab}_{*}}\end{array}$ & $\begin{array}{c}(6.2+ \\
0.4)^{\mathrm{bc}_{*}}\end{array}$ \\
\hline $2.5 \%$ & $(7.16+0.16)^{\mathrm{a} * *}$ & $\begin{array}{c}(7.33+ \\
0.21)^{\mathrm{a} * *}\end{array}$ & $\begin{array}{c}(8.83+ \\
0.16)^{\mathrm{a} * *}\end{array}$ & $\begin{array}{c}(8.0+ \\
0.25)^{\mathrm{a} * *}\end{array}$ & $\begin{array}{c}(7.66+ \\
0.21)^{\mathrm{a} * *}\end{array}$ & $(7.8+0.1)^{\mathrm{a} * *}$ \\
\hline $3.5 \%$ & $(6.5+0.42)^{b} *$ & $\begin{array}{c}(6.5+ \\
0.22)^{\mathrm{abc} *}\end{array}$ & $\begin{array}{c}(6.83+ \\
0.30)^{b_{*}}\end{array}$ & $\begin{array}{c}(6.66+ \\
0.33)^{b_{*}}\end{array}$ & $\begin{array}{l}(5.33+ \\
0.21)^{\mathrm{c}}\end{array}$ & $\begin{array}{c}(6.5+ \\
0.7)^{\mathrm{ab} *}\end{array}$ \\
\hline $5 \%$ & $(6.6+0.33)^{\mathrm{a} *}$ & $\begin{array}{l}(5.66+ \\
0.33)^{c}\end{array}$ & $\begin{array}{c}(5.83+ \\
0.3)^{\mathrm{c}}\end{array}$ & $\begin{array}{l}(6.16+ \\
0.30)^{c}\end{array}$ & $\begin{array}{c}(4.66+ \\
0.33)^{c}\end{array}$ & $\begin{array}{l}(5.3+ \\
0.5)^{\mathrm{c}}\end{array}$ \\
\hline
\end{tabular}

@ Average of six trials

Mean with different superscripts within a same column differ significantly from each other $(\mathrm{P} \leq 0.01)$

* Significant $(\mathrm{P}<0.05)$

$* *$ Highly significant $(\mathrm{P} \leq 0.01)$ 
Fig.1 Acidity and $\mathrm{pH}$ of control and 2.5\% incorporated Orange Flavedo Lassi beverage

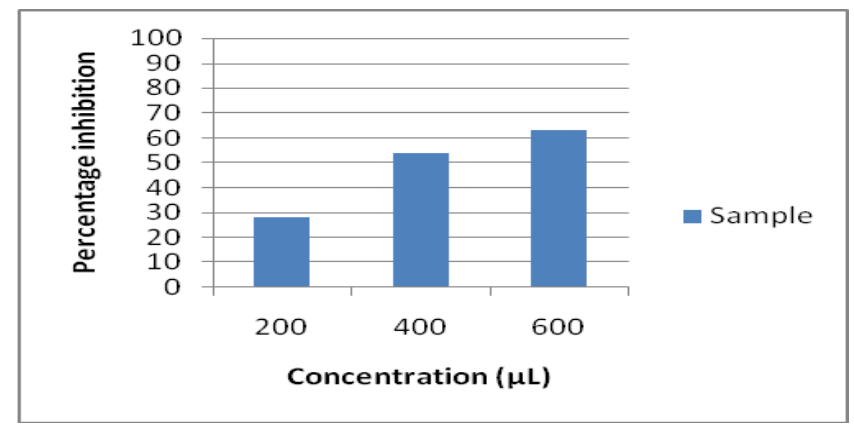

Larrauri (1999) found that the functional components of orange peel are pectin, flavonoides, carotenoides, limonene, and polymethoxy flavones. Pectin acts in glycamic control, reduction in serum cholesterol concentration, cancer prevention and control of mineral balance by All India Institute of Medical Sciences (AIIMS, 2002).Wang et al., (2007) concurred that the main flavonoides present in the citrus peel are hesperidine, narirutine, naringin, and eriocitrin. The flavedo layer has highest antioxidant activity compared to other fractions, but also have antibacterial effects and health promoting capacity (Zamantha et al., 2014). The ability of the extracts to annihilate the DPPH radical (1,1-diphenil-2picrylhydrazyl) was investigated by the method described by Blois (1958).

The acidity of the lassi prepared (control) was $0.42 \%$ LA while the $2.5 \%$ orange flavedo incorporated was found to be $0.36 \%$ LA which was comparable to the normal acidity level of lassi as stipulated by Food Standards and Safety Authority Of India (FSSAI, 2012).

The milk beverages and flavoured milks based on dairy products are receiving a considerable amount of attention, reflecting a growing awareness of these products in market place. Problems with the safety of synthetic essence and flavours have stimulated the research on natural additives. This paper supports the prospects of lassi in the food beverage mix industry, added with some common food additives, without affecting the nutritional and sensory properties, and increases the scope of use of lassi while travelling.

It can be concluded that the milk and fruit based beverage has good keeping quality and high acceptability. The low cost of production could increase its marketability, thereby increasing the milk drinking population.

\section{References}

Adewole, E., D.F. Adewumi, J. Jonathan and Fadaka, 2014. Phytochemical constituents and Proximate Analysis of orange peel (Citrus Fruit). J. Adv. Bot and Zoo.1.pp.2-3.

AIIMS. 2002. Cardiovascular diseases on rise in India. www.indiainfo.com

Aneja, R.P., Mathur, B.N., Chandan, R.C and Banerjee, A.K. 2002.Cultured/ Fermented Products, cited in Technology of Indian Milk Products. A Dairy India Publication, Delhi, India, pp. 165.

Anon, 1997.Dairy India Year Book.Dairy India Publishers, Delhi.

AOAC, 1997. Official methods of analysis of AOAC international, $16^{\text {th }}$ edn(Curniff, P.A. eds). Virginia AOAC international, pp. 25-28.

Blois MS (1958). Antioxidant determinations by the use of a stable free radical, 
Nature, 29: 1199-1200.

FSSAI, 2012.Lab manual 14, FSSAI Manual of methods of analysis of foods microbiological testing.

Hanan, M.E.K., J.K. Youssef and M.A. RashaMousa, 2012.Nutritional assessment of wheat biscuit and fortified wheat biscuits with Citrus Peel Powders.J.Food Pub. Health.2:55-60.

Khurana, H. 2006 Development of technology for extended shelf life fruit lassi. Ph.D Thesis submitted to NDRI.

Larrauri, J. A. 1999. New approaches in the preparation of high dietary fibre powders from fruit by-products.Trends. Food Sci. Technol.10:3-8.

Manus,I.J. 1979. Liquid cultured Dairy Products. Cultured Dairy Products J. 14 (2):9.

Savita, N., S. Salil and K. Asha, 2010. Developement, Nutritional evaluation and Organoleptic evaluation of orange peel candy. Haryana J. Hortic. Sci. 39 (3\&4): 259.
Tiwari, B.D. 1998. Technology of lassi, In: Short Course on Advances in Traditional Dairy Products. Dec, 16-Jan 6,1998. Centre of Advanced Studies in Dairy Technology, NDRI, Karnal, pp 103-106.

VasanthKumar,G., K. Ajay Kumar, G.R. Raghu Patel and S. Manjappa, 2013. Determination of vitamin $\mathrm{C}$ in some fruits and vegetables in Davanagere city, (Karanataka) India.Int. J. Pharm. Life Sci. 4(3): 2489-2491.

Wang, Y. C., Y. C. Chuang and Y. H. Ku, 2007.Quantization of bioactive compounds in citrus fruits cultivated in Taiwan.Food Chem. 102: 1163-1171.

Zamantha E. A., G.U. Janet, V.F. Aurora, J.T. Antonio and W.C. Jorge, 2014.Phytochemicals and antioxidant activity of juice, flavedo, albedo and comminuted orange. J.Funct.foods. $6: 470-481$.

\section{How to cite this article:}

Ananthakumar, K. V. and Rita Narayanan. 2021. Orange Flavedo Incorporated Functional Lassi. Int.J.Curr.Microbiol.App.Sci. 10(01): 2873-2878.

doi: https://doi.org/10.20546/ijcmas.2021.1001.333 